\title{
Nutrition Services in the Integrated Health Service Point: Qualitative Study in Rajeg, Banten.
}

\author{
Tjakradidjaja, F. A*.: Febrianti, $A^{*} ;$ Erfira*; Hiedayati, $N^{*}:$ Ardini, $W^{*}$; Amalia, I**; Firnas, $A^{* * * ; .}$. \\ *Faculty of Medicine and Health Sciences, **Faculty of Psychology, ***Faculty of Social and Political Science, \\ Syarif Hidayatullah State Islamic University \\ Jakarta, Indonesia \\ francisca.tjakradidjaja@uinjkt.ac.id
}

\begin{abstract}
The participation and community involvement in solving health problems is needed. One of the health problems facing is malnutrition. In Indonesia, Posyandu is an Integrated Health Service Point that are organized from, by, and for the community. Posyandu activities run by cadre, the trained community health worker, under coordination and supervision of Puskesmas (Public Health Center). This study aimed to identify wide description of nutrition services in Posyandu. This qualitative study was conducted in rural area. Data collection method: FGD on 10 cadres and 17 mothers and observation Posyandu activities. Subjects purposively recruited and analysis of data using content analysis approach. Posyandu activities performed on a simple building that is provided independently by community. The reason why they want to become a cadre was a personal motivation to perform social works. Unfortunately, there was cadre turnover every turn of the head of the region. Each cadre received training on nutrition services, but in practice, tend not too systematic; not all cadre can fill out the growth chart properly, and there was no respons or counseling be held after nutritional assessment. FGD with mothers stated that cadre were friendly but less communicative, and they did not provide any solution if the child's weight was not increasing. However, they consider that Posyandu help them in maintaining their health. Posyandu services need to be improved. Training and supervision of cadre periodically, providing health care facilities and standardized tools, as well as good coordination between, health workers, and community leaders can optimize the benefits of it.
\end{abstract}

Keywords-- nutrition, integrated health service point, trained health worker

\section{INTRODUCTION}

The number of children under five years in Indonesia by 2015 is $24,065,506$ [1]. Children are the nation's asset that must be maintained for their health so they can become reliable future generations. Other than the government, the public must also participate in taking responsibility of maintaining the next generation such as monitors their growth and development. The community participation in this case is integrated health service point (Posyandu). Posyandu is the spearhead of the public health services [2]. Until now, Posyandu is still considered capable of making efforts to empower families in monitoring growth and development of children and provide caring for infants.

Efforts to develop the quality of human resources by optimizing the potential for child development can be carried out evenly if the community-based health service system, such as Posyandu can be done effectively and efficiently. This service reaches out to all targets e.g. child growth services, pregnant women, lactating mothers, and postpartum mother [3].

There are some of the Posyandu issues summarized by the Ministry of Health as follow: (1) only $40 \%$ of the existing Posyandu, able to perform its functions well, (2) about $50 \%$ of the Posyandu do not have adequate equipment, most Posyandu do not have a decent place of service, because it organizes activities in the warehouse, garage, house, etc. Besides, the guidance on Posyandu is still uneven, (3) most of the Posyandu do not have enough cadre number when compared to the target number and only $30 \%$ of trained cadres, (4). Most of them are dependent on officers from public health centers (Puskesmas) as coaches, meanwhile appreciation for cadres is still low [3].

In 2014, based on the malnutrition reports in Banten Province, the highest malnutrition rate is in Tangerang which reaches 368 children spread in eight villages in Tangerang. In 2016, according to the Rajeg Community Health Center report, there number of malnutrition child are $2.24 \%$ and $0.17 \%$ of children suffering from severe malnutrition. Actually, this figure is not the highest number of malnutrition compared to other villages in the area of Rajeg Community Health Center, but the population growth and the development of population demographic complexity in Rajeg Village is relatively faster as the industry develops in this village [4].

To help overcome the problem of malnutrition in the area of Rajeg Community Health Center, it is needed Posyandu which can carry out its duty well. To know the description of the implementation of Posyandu in Rajeg region this research was done. The result of this study were expected to provide input to improve the Posyandu performance in the future. 


\section{METHODS}

A. Design

This qualitative study was conducted in rural area. Qualitative research can explore the complexity and meaning of social phenomena.

\section{B. Informants}

Ten cadres and 17 mothers were participated in two focus group sessions. Informants purposively recruited. Participants in the focus groups and the observational study were mostly volunteers recruited.

\section{Data collection}

Data collection method were focus group discussion with ten cadres and 17 mothers and observation Posyandu activities. Focus groups are a form of group interview that emphasize on communication between informants in order to generate data. Each focus group discussion session was facilitated by a skilled moderator and lasted about two hours. At the end of each session, informants were asked if they had any other issues they would like to raise. Observation on Posyandu activites was conducted on two Posyandu when they performed the Posyandu services. Field notes and memos were also collected to add contextual meaning to data collected from informants.

\section{Analysis Data}

After conducting the focus discussion group, all the materials were transcribed, printed them and started to highlight what information that would be relevant. Analysis of data using content analysis approach.

\section{RESULTS AND DISCUSSION}

\section{A. Posyandu Activity}

Posyandu was held to provide basic health services such mother and child health, nutrition (growth monitoring, supplemental feeding, vitamin and mineral supplementation, and nutrition education), immunization, family planning and disease control (diarrhea prevention). Considering Posyandu is a community-based effort, it has to be carried out by, from, and for the community. There for the trained cadres which are volunteers from the community are needed. Posyandu activities were carried out by community members who have been trained to become local health cadres under the guidance of Puskesmas. Posyandu managers were administrators formed by RW heads from PKK cadres, formal and informal community leaders and health cadres in the area.

Posyand $u$ were performed at the resident' house and it were implemented by providing five service tables, namely: registration, growth monitoring by measuring the weight and height of children under five years old, recording data to KMS, nutrition and health counselling, and health services by midwife such as immunization. Posyandu services have not been fully implemented with a five-step system or five defined by Kemenkes [3]. The service table at table IV is not optimal yet because the counseling has never been given by the cadres but given by the village midwife. Limitations of cadre knowledge become one of the obstacles. This results in line with previous study $[5,6]$. In contrast to other studies, it was found that cadre was well doing counseling at table IV [7].

Most of Posyandu here did not have proper equipment such as enough tables and standardized weight and height scale. Not all Posyandu have stamped scales. Dacin was not calibrated regularly. Height measurement and baby weighing cannot be done properly, because there was no microtoise tool or baby length board. The absence of adequate infrastructure in the Posyandu was also found in the study conducted by Isra [5] and Sulistyawati [6]. Posyandu that there is no such building, tables and chairs are still using the property of citizens. Facilities such as scales, Kartu Menuju Sehat (KMS) and Sistem Informasi Posyandu (SIP) are prepared by Dinas Kesehatan Kabupaten (DKK). Currently new KMS is not available, while cadre use photocopy of KMS, paper or notebooks to record the weight of toddlers [5].

Sometimes, they even do not have a proper room or building that could provide all mothers and children participants, so it become so crowded and hectic. These children need intensive monitoring every month by cadre and health workers. Cadre finds difficulties to persuade people with nutritional problems. Submission of additional food is sometimes not followed up by Puskesmas.

\section{B. Cadre}

Not all af the cadre had been trained to do all the Posyandu activities. Several of them sould wait for the instruction from the health worker. Trained cadre were often repleced by others untrained cadre when there were local leader replacement. Cadre is a general term used for personnel from the community, chosen by the community and working with the community and to society as a voluntary [3].

There is no communication Barrier between the village midwife and the cadre. This condition makes it easier for the team to invite the cadre to follow the activities because the village midwife motivates the cadre to participate. Village midwives become important figures because they play a role in directing cadre activities. Cadre are asked by the village head to become a cadre. Their education level range is primary to high school level. Motivation to be a posyandu cadre is coming from their self by offering to the village head.

The performance of cadre was not as expected by the Ministry of Health, e.g. in terms of measurement and recording, communication, and nutritional insight. This may be due to a training module that is too complicated and incompatible with the education level of the cadre. This is because the ability of cadre was limited, thus inhibiting the understanding and application of training materials ever given. This phenomenon is also found by Isra [5]. Training that has been implemented is not effective because many trained cadres who drop out so replaced by new cadres who have not experienced. Similar to the research conducted by Sengkey, the services provided by the cadres are good enough although there are still shortcomings [8].

Motivation, knowledge and skills of cadres in the implementation of measurement of weight and height, KMS 
recording, and how to communicate results measurements to mothers should still be improved. Similar result found in the previous study $[5,8]$.

Implementation of a home visit is a cadre task, but the cadre has not done it routinely. Sulistyawati also found the same thing [6].

\section{Mother opinion}

Mothers stated that cadre were friendly but less communicative, and they did not provide any solution if the child's weight was not increasing. This possibility is due to the ineffectiveness of the implementation of the five table services in posyandu, especially table IV. Cadre should have a basic knowledge of the health problems faced by, for example on nutrition, maternal health. [5, 6, 7]. However, they consider that Posyandu help them in maintaining their children health.

Mother feels there were obstacles to visit posyandu regularly. They feel embarrassed because their child body weight did not rise every month. They recognized that the children were happy to visit Posyandu so often remind their mother about Posyandu schedule.

They realize that visiting Posyandu regularly is good for health. The thing that feels lacking was the solution of the health problems which they face. This condition can be understood, due to the limited knowledge of cadres regarding the management of health problems. Cadre should be able to provide direction to the mothers that they can visit community health center if the health problems are too complex [8].

In addition they come to Posyandu, they also believe in traditional medicine to keep children's health. Sometimes they asked for magic charmed that has been recited prayer, performed infant massage or gave the herbal medicine drinking. According to the mothers, Posyandu facilities need to be improved. Feels cramped because many mothers come to visit. Sometimes it also feels dusty.

\section{CONCLUSIONS}

The number of malnutrition children should be suppressed by improving Posyandu services. Training for the cadre is needed so they knew how to measure the weight and height of babies and children correctly, made efficient and detail notes, and motivate and educate mothers who had problems with their children health. These activities should be supervised periodically to evaluate the improvement of their abilities. The local government needed to provide health care facilities and standardized tools so the Posyandu activities could be done properly. As the Posyandu activities are the part of citizen participation in taking a good care of their health so it's needed good coordination between health workers and community leaders. Village leaders' participation in cadre development and provision of the Posyandu infrastructure needs to be improved.

\section{ACKNOWLEDGMENT}

Acknowledgments and appreciation are presented to Lembaga Penelitian dan Pengabdian kepada Masyarakat (LP2M) UIN Jakarta, which has provided this research funding grant.

\section{REFERENCES}

[1] Ministry of Health of Republic Indonesia. Indonesia Health Profile, 2015.

[2] Sondakh, J. J. 'Quality of Health Services and Midwifery".Jakarta: Salemba Medika, 2013

[3] Ministry of Health of Republic Indonesia. "General guidebook of Posyandu service", 2006.

[4] Febrianti, et. al, "UIN Syarif Hidayatullah Jakarta's Community Service Report”, 2016. Unpublished

[5] Isra, W.O., Suryawati C., Kartini A., "Evaluation on the Implementation of Integrated Health Service Post in Decreasing Underfive Protein Energy Malnutrition Cases in Baubau, Southeast Sulawesi Province." Jurna Manajeman Kesehatan Indonesia. Vol 2, No 03, pp 232-241, Desember. 2014

[6] Sulistyawati D., Widagdo L., Purnami C T., "Evaluation on Integerated Health Post Monitoring Process by Health Workers in Singkawang City Primary Healthcare Centers, West Kalimantan". Vol 2, No 1, pp 19-25, April 2014

[7] Sutiani R., Lubis Z., Siagian A., "Description Of Cadres Knowledge And Skills In Monitoring The Growth Of Infant And Under Five Children In Puskesmas Desa Lalang 2014." Cited 2017 Agustus 10th. Available from https://jurnal.usu.ac.id/index.php/gkre/article/viewFile/7612/4326.

[8] Sengkey S., Kandou G.D., Pangemanan J.M., "Performance Analysis of Cadres Posyandu in Puskesmas Paniki Manado." JIKMU, vol 5, No. 2b, Pp 491-502, April, 2015. 